\title{
Natural Killer Cells and Thyroid Diseases
}

\author{
Eun Kyung Lee ${ }^{1,2}$, John B. Sunwoo ${ }^{2}$ \\ ${ }^{1}$ Center for Thyroid Cancer, National Cancer Center, Goyang, Korea; ${ }^{2}$ Department of Otolaryngology-Head and Neck Surgery, \\ Stanford University School of Medicine, Stanford, CA, USA
}

\begin{abstract}
Abnormal production of thyroid hormone is one of the common endocrine disorders, and thyroid hormone production declines with age. The aging process also negatively affects the immune system. An interaction between endocrine system and the immune system has been proposed to be bidirectional. Emerging evidence suggests an interaction between a lymphocyte population, called natural killer (NK) cells and thyroid gland function. Here, we review the relationship between NK cells and thyroid function and disease.
\end{abstract}

Keywords: Killer cells, natural; Thyroiditis; Thyroid cancer, papillary; Anaplastic; Immunotherapy; Programmed cell death 1

\section{INTRODUCTION}

Natural killer (NK) cells are a family of innate immune cells that play an essential role in antiviral immunity and immune surveillance against tumors $[1,2]$. NK cells also influence the development of adaptive immunity through cross-talk with antigen-presenting dendritic cells. Although best known for their ability to kill tumor and virus-infected cells, NK cells also play a role in regulating other immune and nonimmune cells through the production of a variety of cytokines $[3,4]$.

Human NK cells, defined as $\mathrm{CD}^{+} 6^{+} \mathrm{CD}^{-}$cells, compose a subset of the total lymphocyte population (10\%) among peripheral blood mononuclear cells [3]. NK cells are part of the family of group 1 innate lymphoid cells (ILCs), which produce interferon- $\gamma$ (IFN- $\gamma$ ) and tumor necrosis factor $\alpha$ upon stimulation [5]. Unlike ILC1s, NK cells have cytotoxic activity, similar to $\mathrm{CD} 8^{+}$cytotoxic T lymphocytes $[6,7]$.

Activated NK cells which have been cultured with several cytokines such as interleukin-2 (IL-2), IL-12, IL-15, and IL-18 are also able to lyse certain target cells [8,9]. Subtypes of human NK

Received: 27 May 2019, Revised: 30 May 2019, Accepted: 7 June 2019

Corresponding author: John B. Sunwoo

Department of Otolaryngology-Head and Neck Surgery, Stanford University School of Medicine, 801 Welch Rd, Stanford, CA 94305, USA

Tel: +1-650-725-6500, Fax: +1-650-725-8502, E-mail: sunwoo@stanford.edu cells have traditionally been described on the basis of their relative expression of CD16 and CD56 cell surface antigens [1,4, 10]. In broad terms, there are two main subsets in the peripheral circulation, $\mathrm{CD} 56{ }^{\mathrm{dim}} \mathrm{CD} 16^{+}$more mature NK cells $(95 \%)$ and CD56 ${ }^{\text {bright }} \mathrm{CD} 16^{-}$more immature NK cells (5\%) [3]. Recently, apart from the circulating NK cell in peripheral blood, specific tissue resident NK cell subpopulations in the liver, uterus, and skin have been described [11,12].

The $\mathrm{CD} 56^{\mathrm{dim}} \mathrm{CD} 16^{+} \mathrm{NK}$ cells have high cytotoxic activity with innate potential for killing certain tumor cells without prior stimulation, whereas $\mathrm{CD} 56^{\text {bright }} \mathrm{CD} 16^{- \text {llow }} \mathrm{NK}$ cells are more efficient for cytokine-mediated immunity [13]. CD56 $6^{\text {bight }}$ cells may orchestrate overall immunity due to their ability to generate large amounts of cytokines during stimulation [3].

NK cell function is regulated by integrating the signals from numerous activating and inhibitory receptors [3]. The activating receptors, which recognize highly expressed molecules on virus-infected cells or tumor cells, include natural killer group 2, member D (NKG2D), the natural cytotoxicity receptors (NCRs) NKp30 (also known as NCR3) and NKp46 (also known as

\section{Copyright () 2019 Korean Endocrine Society}

This is an Open Access article distributed under the terms of the Creative Commons Attribution Non-Commercial License (http://creativecommons.org/ licenses/by-nc/4.0/) which permits unrestricted non-commercial use, distribution, and reproduction in any medium, provided the original work is properly cited. 
NCR1), and DNAX accessory molecule 1 (DNAM1; also known as CD226). The inhibitory receptors, such as killer cell immunoglobulin-like receptors (KIRs) and CD94-NKG2A, mostly recognize major histocompatibility complex (MHC) class I molecules (i.e., human leukocyte antigen [HLA] in humans). It is through this interaction between NK cell inhibitory receptors and MHC I that NK cells distinguish "self" from "non-self" (cells that have lost or downregulated expression of MHC I). In addition to these regulation mechanisms, NK cells also respond to cytokines such as IFN- $\alpha$, IL-12, IL-15, and IL-18, which can be produced by nearby cells.

A number of reports indicate an interaction between NK cells and thyroid gland function and disease processes. Here, we review what is known about NK cells in thyroid disorders.

\section{THYROID HORMONE EFFECTS ON NK CELL ACTIVITY}

An interest in the link between immune system and thyroid hormone status comes from the fact that thyroid stimulating hormone can bind to peripheral blood mononuclear cells (including monocytes, NK cells and activated B cells) [14]. With aging, both the innate and adaptive arms of the immune system are affected, and such changes can increase susceptibility to infections, cancer, and autoimmune diseases [15]. Because absolute or relative deficiency of thyroid hormone is prevalent in the elderly, thyroid hormone deficiency has been proposed to be involved with this aging-dependent immune dysregulation. In line with this, the cytolytic activity of NK cells, isolated from older human subjects, has been demonstrated to be suppressed compared to those from younger subjects, and interestingly, this diminished activity was restored by triiodothyronine (T3) [16]. These results are consistent with findings from a murine model, where exogenous administration of thyroxine resulted in the augmentation of NK cell activity $[17,18]$. NK cell activity was also studied in the context of patients undergoing thyroidectomy for early stage thyroid cancer; the thyroxine suppressive treatment increased serum IL-18 concentrations and the percentage of activated NK cells in peripheral blood, compared with controls [19]. Conversely, after thyroxine withdrawal, serum levels of IL-18, and the percentage of NK cells decreased progressively. Thyroid hormones have also been shown to potentially affect NK cell cytokine production. T3, for example, can induce IL-2 receptor expression in peripheral blood mononuclear cells [20]. Administration of low doses of thyroxine enhanced the stimulatory effect of IFN on NK cells [21].
Thus, there is evidence of an interaction between thyroid function and NK cell activity. The mechanisms underlying these phenomena are poorly understood and warrant further study.

\section{NK CELLS AND THYROID AUTOIMMUNE DISEASE}

NK cell function appears to be affected several autoimmune diseases such as systemic lupus erythematosus (SLE) [7,22,23]. SLE develops from a non-tissue-specific autoimmune reaction and characterized by the activation of polyclonal B cells and the production of autoantibodies against several nuclear proteins [23]. NK cells show a variable NK cell deficiency and cytotoxic defect in SLE patients.

Regarding autoimmune thyroid disease, contradicting observations on disease states and NK cell activity have been reported. One study reported that patients with Hashimoto's thyroiditis, Graves' disease, or nontoxic goiter, and normal controls did not differ in NK cell activity [24]. In addition, there was no correlation between NK cell activity and antithyroid antibodies (thyroglobulin antibody, thyroperoxidase antibody [TPO-Ab], and thyroid stimulating antibody). Considering that NK cell activity is affected by age, another study compared patients with Graves' disease and Hashimoto's thyroiditis to age and gendermatched healthy controls; this study demonstrated that NK cell activity was significantly reduced in both groups compared to the normal controls [25]. In both Graves' disease and Hashimoto's thyroiditis, NK activity was not correlated with serum thyroxine concentration, presence of ophthalmopathy, or serum thyroid antibody titer, and goiter size. In another study, NK cell function was reduced in hyperthyroid patients regardless of underlying pathology (Graves' disease or Hashimoto's thyroiditis), though the number of NK cells was not decreased [26].

The role of NK cell in postpartum thyroiditis has also been studied. Physiologically NK cell activity minimally decreased in late pregnancy and increased in the postpartum period in normal women [27]. In an early study for postpartum thyroiditis, NK cell activity was depressed after delivery, but there were no differences between postpartum thyroiditis patients and healthy postpartum women [28]. Another study showed opposite results that in repetitive measurement in pre and postpartum in the same patients, NK activity was significantly higher than those in the euthyroid state with postpartum Graves' disease or with postpartum destructive thyroiditis [27]. However, these studies did not include an analysis of the results of TPO-Ab, which is associated with the development and disease activity of postpar- 
tum thyroiditis. In a Dutch prospective study, depression of NK cell activity occurred in only TPO-Ab positive postpartum thyroiditis, but not in TPO-Ab negative postpartum thyroiditis or normal pregnancy [29]. This finding suggested postpartum thyroiditis can be divided into two subtypes according to the presence of TPO-Ab, and TPO-Ab positive postpartum thyroiditis induced immunological perturbations in NK cell activity.

Antithyroid drugs, especially propylthiouracil, are well known to have immunosuppressive effects [30]. As a result, in patients taking antithyroid drugs, serum concentrations of antithyroid antibodies decrease with time [31]. Furthermore, antithyroid drug treatment induces an increased number of circulating suppressor $\mathrm{T}$ cells and a decreased number of helper $\mathrm{T}$ cells, NK cells, and activated intrathyroidal T cells $[30,32]$.

\section{NK CELLS AND CANCER}

The protective role of NK cell during carcinogenesis is suggested by observations that low cytotoxic activity of NK cell is associated with increased cancer risk [8,33,34]. In a murine experimental model, NK cell-deficient mice more efficiently developed spontaneous and carcinogen-induced tumors [35,36].

NK cells differentiate target cells from 'healthy self' by integrating signals from multiple inhibitory and activating receptors. NK cells represent an attractive lymphocyte population for cancer immunotherapy due to their ability to lyse tumor targets without prior sensitization and without need for HLA-matching [37,38]. In addition, NK cells have the ability to react quickly, producing a broad range of cytokines within minutes to hours of antigenic stimulation and also activate antigen-presenting dendritic cells. This rapid effect can trigger powerful innate and acquired immune responses both directly and indirectly. Clinical trials using NK cells demonstrated acceptable efficacy in patients with refractory acute myelogenous leukemia, breast cancer and ovarian cancer [39-41].

Nevertheless, very few solid tumors have been shown to respond to NK cell-mediated immunotherapy possibly due to a number of mechanisms, including resistance to NK cell-induced cytotoxicity and/or poor tumor infiltration by NK cells. Immunosuppressive factors released from the tumor microenvironment (TME), such as transforming growth factor $\beta 1$ (TGF- $\beta 1$ ), rendered intratumoral NK cells dysfunctional compared to circulating NK cells [42].

To enhance NK cell activity, many studies have explored the use of cytokines to improve NK cell proliferation and cytotoxicity. IL-2 was first identified as a stimulator for expansion of T cell lymphocyte, so IL-2 treatment was approved as the first immunotherapy by U.S. Food and Drug Administration for kidney cancer in 1992 and melanoma in 1998 [43]. IL-15 is also critical for NK cell maturation and survival [44] and an engineered IL15 superagonist/IL-15R $\alpha$ fusion complex activates the IL-15 receptor on $\mathrm{CD}^{+} \mathrm{T}$ cells and NK cells, and overcome TGF $\beta 1-$ induced suppression of NK cell cytotoxicity in vivo and in vitro studies [42]. NK, as well as $\mathrm{CD}^{+} \mathrm{T}$ cells, were important mediators of this cytotoxicity, and the reduced cytotoxic capacity of splenocytes in tumor-bearing mice was partially restored by treatment with exogenous IL-12 and anti-TGF $\beta$ [45].

\section{OBSERVATIONS ABOUT THE ASSOCIATION OF NK CELLS AND THYROID CANCER}

The role of NK cells has been studied in thyroid cancer as well. In papillary thyroid carcinoma (PTC) patients, NK cell infiltration was greater in earlier stage disease compared to late stage disease [46]. Flow cytometry analysis on tissue samples and peripheral blood from PTC and multinodular goiter (MNG) patients showed that tumor-infiltrating NK cells were increased in PTCs compared to goiters and healthy thyroids, whereas no differences were found in peripheral blood NK cells [46]. More specifically, CD56 ${ }^{\text {bright }} \mathrm{NK}$ cells were increased in PTC samples compared to MNG and inversely correlated with the disease stage, whereas cytotoxic NK cells positively correlated with the disease stage in PTC patients [47]. When compared with anaplastic thyroid cancer (ATC), the frequency of the CD56 $6^{\text {hi }} \mathrm{CD}$ $16^{\text {hilo }} \mathrm{NK}$ subset was significantly higher in more advanced thyroid cancer patients and further increased in ATC patients, though $>90 \%$ of circulating NK cells were $\mathrm{CD} 56^{\text {lo }} \mathrm{CD} 16^{\text {hi }}$ and fewer than $10 \%$ were $\mathrm{CD} 56^{\mathrm{hi}} \mathrm{CD} 16^{\mathrm{hi} / \mathrm{lo}}$ in healthy controls and early stage thyroid cancer patients [48]. These findings suggest that modulation of cell phenotype can occur in the TME of thyroid cancer.

To investigate the mechanism of NK cell mobilization in thyroid cancer, the C-X-C motif chemokine ligand 10 (CXCL10)C-X-C motif chemokine receptor 3 (CXCR3) axis was assessed in several studies. Mast cell-derived CXCL1/growth-regulated oncogene $\alpha(\mathrm{GRO}-\alpha)$ and CXCL10/interferon $\gamma$-induced protein 10 (IP10) production increased ATC proliferation through the engagement of CXCR2 and CXCR3 expressed on thyroid cells [49]. Interestingly, the activation of the CXCL10-CXCR3 axis was also induced by NK cell migration in ATC cell lines. Prostaglandin-E2 was identified as the main factor responsible for 
the ATC-mediated NK cell suppression [50].

As mentioned previously, NKG2D is an activation receptor for NK cells, which potentiates the lysis of tumor cells. ATC cell lines are sensitive to lysis by ex vivo expanded NK cells, and this lysis is abrogated upon blockade of NKG2D [50]. ATC cell lines derived from fine-needle aspiration (FNA) biopsy samples from ATC patients expressed UL16-binding proteins (ULBP) $2 / 5 / 6$, which is the ligand of NKG2D surface receptor recognizing infected or tumor transformed cells, whereas nonmalignant thyroid tissue did not, possibly explaining one way NK cells respond to ATC [50]. Flow cytometry analysis of NK cells from FNA and peripheral blood of ATC patients, however, has revealed that the NK cells have a suppressed phenotype, characterized by a lower percentage of CD56 $6^{\text {dim }}$ cells and $\mathrm{CXCR}^{+}$cells and a reduced $\mathrm{NKG} 2 \mathrm{D}$ expression, compared to peripheral blood NK cells [50].

Several ways to improve NK cell activity against thyroid cancer have been investigated. IL-12 has been shown to improve the cytotoxic activity of $\mathrm{CD}^{+} \mathrm{T}$ cells and NK cells in PTC and increase the infiltration of M1 macrophages compared to alternative M2 macrophages within the tumors [45]. It has also been demonstrated that ATC cells expressing high levels of cyclooxygenase 2 (COX2) co-cultured with NK cells resulted in downregulation of NKG2D expression on NK cells when compared with co-culture of COX2-negative cell lines [50]. This downregulation of NKG2D was rescued by administration of neutralizing antibodies to prostaglandin-E2.

\section{CONCLUSIONS}

NK cells orchestrate the innate and adaptive immunity interacting other immune cells and differentiating tumor cells. The altered NK cell activity observed in many thyroid disease may have important implication for the clinical behavior of these disorders. There is need for further research and understanding of these processes.

\section{CONFLICTS OF INTEREST}

John B. Sunwoo is a member of the scientific advisory board and scientific co-founder of Indapta Biotherapeutics, and a member of the scientific advisory boards of ABL Bio and Vigilant Biosciences. He receives grant funding from the National Institutes of Health (U.S.A.) and the Parker Institute for Cancer Immunotherapy.

\section{ORCID}

Eun Kyung Lee https://orcid.org/0000-0003-0098-0873

John B. Sunwoo https://orcid.org/0000-0002-8393-4196

\section{REFERENCES}

1. Robertson MJ, Ritz J. Biology and clinical relevance of human natural killer cells. Blood 1990;76:2421-38.

2. Galdiero MR, Varricchi G, Marone G. The immune network in thyroid cancer. Oncoimmunology 2016;5:e1168556.

3. Bjorkstrom NK, Ljunggren HG, Michaelsson J. Emerging insights into natural killer cells in human peripheral tissues. Nat Rev Immunol 2016;16:310-20.

4. Vivier E, Tomasello E, Baratin M, Walzer T, Ugolini S. Functions of natural killer cells. Nat Immunol 2008;9:50310.

5. Xu D. Regulation of inflammatory signaling in health and disease. Singapore: Springer Singapore; 2017. Chapter 11, The development and diversity of ILCs, NK cells and their relevance in health and diseases; p. 225-44.

6. Spits H, Artis D, Colonna M, Diefenbach A, Di Santo JP, Eberl G, et al. Innate lymphoid cells: a proposal for uniform nomenclature. Nat Rev Immunol 2013;13:145-9.

7. Abel AM, Yang C, Thakar MS, Malarkannan S. Natural killer cells: development, maturation, and clinical utilization. Front Immunol 2018;9:1869.

8. Brittenden J, Heys SD, Ross J, Eremin O. Natural killer cells and cancer. Cancer 1996;77:1226-43.

9. Farag SS, VanDeusen JB, Fehniger TA, Caligiuri MA. Biology and clinical impact of human natural killer cells. Int J Hematol 2003;78:7-17.

10. Wang F, Tian Z, Wei H. Genomic expression profiling of NK cells in health and disease. Eur J Immunol 2015;45:66178.

11. Horowitz A, Strauss-Albee DM, Leipold M, Kubo J, NematGorgani N, Dogan OC, et al. Genetic and environmental determinants of human NK cell diversity revealed by mass cytometry. Sci Transl Med 2013;5:208ra145.

12. Marquardt N, Beziat V, Nystrom S, Hengst J, Ivarsson MA, Kekalainen E, et al. Cutting edge: identification and characterization of human intrahepatic CD49a+ NK cells. J Immunol 2015;194:2467-71.

13. Cooper MA, Fehniger TA, Caligiuri MA. The biology of human natural killer-cell subsets. Trends Immunol 2001;22:63340. 
14. Coutelier JP, Kehrl JH, Bellur SS, Kohn LD, Notkins AL, Prabhakar BS. Binding and functional effects of thyroid stimulating hormone on human immune cells. J Clin Immunol 1990;10:204-10.

15. Mocchegiani E, Malavolta M. NK and NKT cell functions in immunosenescence. Aging Cell 2004;3:177-84.

16. Kmiec Z, Mysliwska J, Rachon D, Kotlarz G, Sworczak K, Mysliwski A. Natural killer activity and thyroid hormone levels in young and elderly persons. Gerontology 2001;47: 282-8.

17. Sharma SD, Tsai V, Proffitt MR. Enhancement of mouse natural killer cell activity by thyroxine. Cell Immunol 1982; 73:83-97.

18. Provinciali M, Muzzioli M, Di Stefano G, Fabris N. Recovery of spleen cell natural killer activity by thyroid hormone treatment in old mice. Nat Immun Cell Growth Regul 1991; 10:226-36.

19. Botella-Carretero JI, Prados A, Manzano L, Montero MT, Escribano L, Sancho J, et al. The effects of thyroid hormones on circulating markers of cell-mediated immune response, as studied in patients with differentiated thyroid carcinoma before and during thyroxine withdrawal. Eur J Endocrinol 2005;153:223-30.

20. Dorshkind K, Horseman ND. The roles of prolactin, growth hormone, insulin-like growth factor-I, and thyroid hormones in lymphocyte development and function: insights from genetic models of hormone and hormone receptor deficiency. Endocr Rev 2000;21:292-312.

21. Provinciali M, Fabris N. Modulation of lymphoid cell sensitivity to interferon by thyroid hormones. J Endocrinol Invest 1990;13:187-91.

22. Johansson S, Berg L, Hall H, Hoglund P. NK cells: elusive players in autoimmunity. Trends Immunol 2005;26:613-8.

23. Schleinitz N, Vely F, Harle JR, Vivier E. Natural killer cells in human autoimmune diseases. Immunology 2010;131:4518.

24. Pedersen BK, Feldt-Rasmussen U, Bech K, Perrild H, Klarlund K, Hoier-Madsen M. Characterization of the natural killer cell activity in Hashimoto's and Graves' diseases. Allergy 1989;44:477-81.

25. Wenzel BE, Chow A, Baur R, Schleusener H, Wall JR. Natural killer cell activity in patients with Graves' disease and Hashimoto's thyroiditis. Thyroid 1998;8:1019-22.

26. Papic M, Stein-Streilein J, Zakarija M, McKenzie JM, Guffee J, Fletcher MA. Suppression of peripheral blood natural killer cell activity by excess thyroid hormone. J Clin In- vest 1987;79:404-8.

27. Hidaka Y, Amino N, Iwatani Y, Kaneda T, Nasu M, Mitsuda $\mathrm{N}$, et al. Increase in peripheral natural killer cell activity in patients with autoimmune thyroid disease. Autoimmunity 1992;11:239-46.

28. Hayslip CC, Baker JR Jr, Wartofsky L, Klein TA, Opsahl MS, Burman KD. Natural killer cell activity and serum autoantibodies in women with postpartum thyroiditis. J Clin Endocrinol Metab 1988;66:1089-93.

29. Kuijpens JL, De Hann-Meulman M, Vader HL, Pop VJ, Wiersinga WM, Drexhage HA. Cell-mediated immunity and postpartum thyroid dysfunction: a possibility for the prediction of disease? J Clin Endocrinol Metab 1998;83:1959-66.

30. Cooper DS. Antithyroid drugs. N Engl J Med 2005;352:90517.

31. McGregor AM, Petersen MM, McLachlan SM, Rooke P, Smith BR, Hall R. Carbimazole and the autoimmune response in Graves' disease. N Engl J Med 1980;303:302-7.

32. Wang PW, Luo SF, Huang BY, Lin JD, Huang MJ. Depressed natural killer activity in Graves' disease and during antithyroid medication. Clin Endocrinol (Oxf) 1988;28:20514.

33. Mandal A, Viswanathan C. Natural killer cells: in health and disease. Hematol Oncol Stem Cell Ther 2015;8:47-55.

34. Imai K, Matsuyama S, Miyake S, Suga K, Nakachi K. Natural cytotoxic activity of peripheral-blood lymphocytes and cancer incidence: an 11-year follow-up study of a general population. Lancet 2000;356:1795-9.

35. Haliotis T, Ball JK, Dexter D, Roder JC. Spontaneous and induced primary oncogenesis in natural killer (NK)-cell-deficient beige mutant mice. Int J Cancer 1985;35:505-13.

36. Guerra N, Tan YX, Joncker NT, Choy A, Gallardo F, Xiong $\mathrm{N}$, et al. NKG2D-deficient mice are defective in tumor surveillance in models of spontaneous malignancy. Immunity 2008;28:571-80.

37. Hermanson DL, Kaufman DS. Utilizing chimeric antigen receptors to direct natural killer cell activity. Front Immunol 2015;6:195.

38. Vivier E, Raulet DH, Moretta A, Caligiuri MA, Zitvogel L, Lanier LL, et al. Innate or adaptive immunity? The example of natural killer cells. Science 2011;331:44-9.

39. Miller JS, Soignier Y, Panoskaltsis-Mortari A, McNearney SA, Yun GH, Fautsch SK, et al. Successful adoptive transfer and in vivo expansion of human haploidentical NK cells in patients with cancer. Blood 2005;105:3051-7.

40. Geller MA, Cooley S, Judson PL, Ghebre R, Carson LF, Ar- 
genta PA, et al. A phase II study of allogeneic natural killer cell therapy to treat patients with recurrent ovarian and breast cancer. Cytotherapy 2011;13:98-107.

41. Romee R, Rosario M, Berrien-Elliott MM, Wagner JA, Jewell BA, Schappe T, et al. Cytokine-induced memory-like natural killer cells exhibit enhanced responses against myeloid leukemia. Sci Transl Med 2016;8:357ra123.

42. Fujii R, Jochems C, Tritsch SR, Wong HC, Schlom J, Hodge JW. An IL-15 superagonist/IL-15R $\alpha$ fusion complex protects and rescues NK cell-cytotoxic function from TGF- $\beta 1$ mediated immunosuppression. Cancer Immunol Immunother 2018;67:675-89.

43. Spolski R, Li P, Leonard WJ. Biology and regulation of IL2: from molecular mechanisms to human therapy. Nat Rev Immunol 2018;18:648-59.

44. Cooper MA, Bush JE, Fehniger TA, VanDeusen JB, Waite $\mathrm{RE}$, Liu $\mathrm{Y}$, et al. In vivo evidence for a dependence on interleukin 15 for survival of natural killer cells. Blood 2002;100: 3633-8.

45. Parhar RS, Zou M, Al-Mohanna FA, Baitei EY, Assiri AM, Meyer BF, et al. IL-12 immunotherapy of Braf(V600E)-induced papillary thyroid cancer in a mouse model. Lab Invest
2016;96:89-97.

46. Gogali F, Paterakis G, Rassidakis GZ, Kaltsas G, Liakou CI, Gousis P, et al. Phenotypical analysis of lymphocytes with suppressive and regulatory properties (Tregs) and NK cells in the papillary carcinoma of thyroid. J Clin Endocrinol Metab 2012;97:1474-82.

47. Gogali F, Paterakis G, Rassidakis GZ, Liakou CI, Liapi C. CD3(-)CD16(-)CD56(bright) immunoregulatory NK cells are increased in the tumor microenvironment and inversely correlate with advanced stages in patients with papillary thyroid cancer. Thyroid 2013;23:1561-8.

48. Yin M, Di G, Bian M. Dysfunction of natural killer cells mediated by PD-1 and Tim-3 pathway in anaplastic thyroid cancer. Int Immunopharmacol 2018;64:333-9.

49. Melillo RM, Guarino V, Avilla E, Galdiero MR, Liotti F, Prevete N, et al. Mast cells have a protumorigenic role in human thyroid cancer. Oncogene 2010;29:6203-15.

50. Wennerberg E, Pfefferle A, Ekblad L, Yoshimoto Y, Kremer V, Kaminskyy VO, et al. Human anaplastic thyroid carcinoma cells are sensitive to NK cell-mediated lysis via ULBP2/5/6 and chemoattract NK cells. Clin Cancer Res 2014;20:573344. 